Original Paper

\title{
Generation of Reactive Oxygen Species by Interaction between Antioxidants Used as Food Additive and Metal Ions
}

\author{
Yusuke Iwasaki* ${ }^{*}$, Momoko Oda, Yuri Tsukuda, Yuki Nagamori, \\ Hiroyuki NakazaWa, Rie Ito and Koichi Saito \\ Department of Analytical Chemistry, Hoshi University School of Pharmacy and Pharmaceutical Sciences: \\ 2-4-41 Ebara, Shinagawa-ku, Tokyo 142-8501, Japan; \\ * Corresponding author
}

\begin{abstract}
Food additives, such as preservatives, sweeteners, coloring agents, and flavoring agents, are widely used in food manufacturing. However, their combined effects on the human body are not known. The purpose of this study was to examine whether combinations of antioxidants and metal ions generate reactive oxygen species (ROS) under in vitro conditions using electron spin resonance (ESR). Among the metal ions examined, only iron and copper generated ROS in the presence of antioxidants. Moreover, certain phenolic antioxidants having pro-oxidant activity induced DNA oxidation and degradation via the generation of high levels of ROS in the presence of copper ion, resulting in complete degradation of DNA in vitro.
\end{abstract}

(Received December 24, 2013)

Key words: antioxidant; food additive; metal ion; oxidative stress; reactive oxygen species

\section{Introduction}

Food additives, such as preservatives, sweeteners, coloring agents, and flavoring agents, are commonly used in food manufacturing. The use of food additives is regulated by the Ministry of Health, Labour and Welfare in Japan, based on doses determined not to adversely affect human health by the Food Safety Commission.

Food additives are classified as specified additives and existing additives. Existing additives are additives that have been used for a long time in Japan. However, madder color, a food coloring extracted from the roots of Rubia tinctorum L., has been deleted from the list of existing additives because it was reported to induce renal carcinogenesis ${ }^{1,2)}$ following a re-evaluation of food additives. The European Food Safety Authority (EFSA) has initiated an internal mandate for preparing refined exposure calculations for food colors re-evaluated since $2010^{* 1, * 2}$.

The FAO/WHO Joint Expert Committee on Food Additives (JECFA) and the Joint FAO/WHO Meeting on Pesticide Residues (JMPR) determine the acceptable daily intake (ADI) based on all the facts available at the time

* iwasaki@hoshi.ac.jp

*1 Commission Regulation (EU) No. 257/2010 of 25 March 2010 setting up a programme for the re-evaluation of approved food additives in accordance with Regulation (EC) No. 1333/2008 of the European Parliament and of the Council on food additives.

*2 Food additive re-evaluations given fresh impetus with new call for data, 27 March 2013, http://www.efsa.europa.eu/en/ press/news/130327.htm of evaluation. JECFA generally sets ADI values based on the lowest relevant no-observed-adverse-effect level (NOAEL) in the most sensitive test species. The ADI values for food additives are commonly derived from NOAEL values in long-term in vivo studies in animals. To derive an ADI value, a safety or uncertainty factor (commonly 100) is applied to the NOAEL in the most sensitive test species. However, unexpected effects caused by combined reactions may arise, because the ADI is determined for single compounds. There are many components in food and drink; thus, it is quite likely that interactions occur in the human body.

In our previous study, we found that phenolic compounds with antioxidant activity react with metal ions (particularly copper ion), generating reactive oxygen species $(\mathrm{ROS})^{3)}$. Caffeic acid (CaA), a phenolic compound, reacted with sodium nitrite in artificial gastric juice, forming new products via generation of reactive nitrogen species $(\mathrm{RNS})^{4)}$.

Antioxidants are added to many foods to prevent the degradation of food components and degradation or fading of food colors. Generally speaking, antioxidants scavenge ROS and inhibit ROS-induced oxidative DNA damage. However, phenolic compounds are redox agents and can act as pro-oxidants under certain conditions. It seems likely that this is also the case for other antioxidants.

The purpose of this study was to examine the interaction of antioxidants with metal ions in vitro, using electron spin resonance (ESR), in order to determine whether these is a potential risk to human health. 


\section{Materials and Methods}

\section{Chemicals and reagents}

The chemical structures of the antioxidants used in this study are shown in Fig. 1. L-Ascorbic acid (Asc) was obtained from Kanto Chemical (Tokyo, Japan). 3,4-Dihydroxycinnamic acid (caffeic acid; CaA), trans-4-hydroxy3-methoxycinnamic acid (ferulic acid; FA), gallic acid (GA), glycyrrhizin (Gly), $\gamma$-oryzanol (Ory), quercetin dihydrate (Que), rutin (Rut), $\gamma$-tocopherol (Toc), and 2,6-di-t-butyl-4-methylphenol (butylhydroxytoluene; BHT) were obtained from Wako Pure Chemical Industries (Tokyo, Japan). Carnosic acid (Car), (+)-catechin (Cat), chlorogenic acid (ChA), eugenol (Eug), phytic acid (PA), sesamin (Semin), sesamol (Semol), and 4-hydroxy3-tert-butylanisole (BHA) were purchased from Tokyo Chemical Industry (Tokyo, Japan).

Sodium chloride $\left(\mathrm{Na}^{+}\right)$, magnesium chloride $\left(\mathrm{Mg}^{2+}\right)$, potassium chloride $\left(\mathrm{K}^{+}\right)$, calcium chloride $\left(\mathrm{Ca}^{2+}\right)$, manganese(II) acetate tetrahydrate $\left(\mathrm{Mn}^{2+}\right)$, manganese(IV) oxide $\left(\mathrm{Mn}^{4+}\right)$, iron(III) chloride $\left(\mathrm{Fe}^{3+}\right)$, copper(I) chloride $\left(\mathrm{Cu}^{+}\right)$, and zinc chloride $\left(\mathrm{Zn}^{2+}\right)$ were purchased from Wako Pure Chemical Industries. Chromium(III) chloride hexahydrate $\left(\mathrm{Cr}^{3+}\right)$, ammonium iron(II) sulfate hexahydrate $\left(\mathrm{Fe}^{2+}\right)$ and copper(II) sulfate pentahydrate $\left(\mathrm{Cu}^{2+}\right)$ were obtained from Kanto Chemical.

$\alpha$-(4-Pyridyl-1-oxide)- $N$-tert-butylnitrone (POBN) as a spin-trapping reagent and 1,1-diphenyl-2-picrylhydrazyl
(DPPH) were obtained from Tokyo Chemical Industry. Dimethyl sulfoxide (DMSO), hydrogen peroxide (30\%), and nuclease P1 were obtained from Wako Pure Chemical Industries. Ethylenediamine- $N, N, N^{\prime}, N^{\prime}$-tetraacetic acid, disodium salt (EDTA) and bathocuproinedisulfonic acid disodium salt (BCS) were obtained from Dojindo Laboratories (Kumamoto, Japan). Catalase (CAT), deferoxamine mesylate salt (DFO), deoxyribonucleic acid sodium salt from calf thymus, phosphatase alkaline from bovine intestinal mucosa, 2'-deoxyguanosine (dG), and 8-hydroxy-2'-deoxyguanosine (8-OHdG) were obtained from Sigma (Tokyo, Japan). 2'-Deoxyguanosine${ }^{13} \mathrm{C}_{1}{ }^{15} \mathrm{~N}_{2}\left(\mathrm{dG}-{ }^{13} \mathrm{C}_{1},{ }^{15} \mathrm{~N}_{2}\right)$ and 8-hydroxy-2'-deoxyguanosine${ }^{13} \mathrm{C}_{1}{ }_{15} \mathrm{~N}_{2}$ (8-OHdG- ${ }^{13} \mathrm{C}_{1},{ }^{15} \mathrm{~N}_{2}$ ) used as an internal standard (IS) were purchased from Toronto Research Chemicals (Toronto, USA).

Ultrapure water was provided by a Milli-Q integral 3 system. Other chemicals and solvents were obtained from Wako Pure Chemical Industries.

\section{2. $D P P H$ radical-scavenging activity}

The modified DPPH method was used for determination of antioxidant activity ${ }^{3), 4)}$. DPPH radical solution $(0.1 \mathrm{mmol} / \mathrm{L})$ was prepared in methanol and the antioxidants were diluted with methanol to concentrations ranging from 0.1 to $2 \mathrm{mmol} / \mathrm{L}$. In a $1.5 \mathrm{~mL}$ disposable tube, the prepared DPPH $(200 \mu \mathrm{L})$ solution was added to a sample of diluted antioxidant $(200 \mu \mathrm{L})$. The mixed

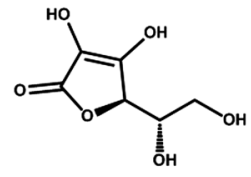

Ascorbic acid (Asc)<smiles>O=C(O)/C=C/c1ccc(O)c(O)c1</smiles>

Caffeic acid (CaA)

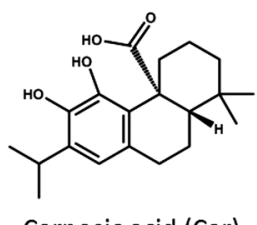

Carnosic acid (Car)<smiles>Oc1cc(O)c2c(c1)OC(c1ccc(O)c(O)c1)C(O)C2</smiles>

Catechin (Cat)<smiles>C1CCCOCC1</smiles><smiles>O=C(/C=C/c1ccc(F)c(I)c1)O[C@H]1C[C@@](O)(C(=O)O)C[C@H](O)[C@H]1O</smiles><smiles>C=CCc1ccc(O)c(OC)c1</smiles>

Eugenol (Eug)<smiles>COc1cc(/C=C/C(=O)O)ccc1O</smiles>

Ferulic acid (FA)<smiles>O=C(O)c1cc(O)c(O)c(O)c1</smiles>

Gallic acid (GA)

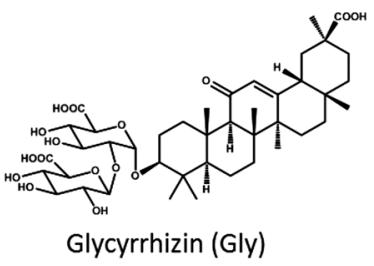

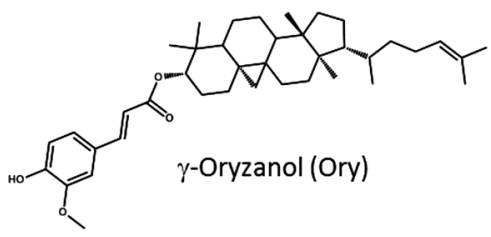

Fig. 1. Chemical structures of antioxidants examined 


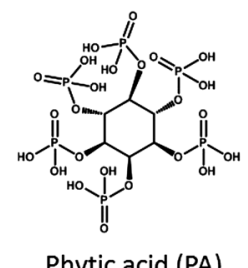<smiles>O=c1c(O)c(-c2ccc(O)c(O)c2)oc2cc(O)cc(O)c12</smiles>

Quercetin (Que)

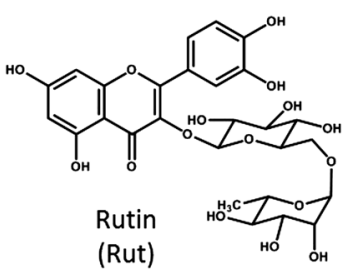<smiles>C[C@]12COC(c3ccc4c(c3)OCO4)C1COC2c1ccc2c(c1)OCO2</smiles>

Sesamin (Semin)<smiles>[2H]c1c(C)c(C)c2c(c1C)OC(CCCC(=O)O)(CCCC(C)CCCC(C)CCCC(C)C)CC2</smiles>

(Toc)<smiles>Oc1ccc2c(c1)OCO2</smiles><smiles>COc1ccc(O)c(C(C)(C)C)c1</smiles>

4-hydroxy-3-tertbutylanisole (BHA)<smiles>CCCCc1cc(C)cc(CCCC)c1C</smiles>

Butylhydroxytoluene (BHT)

Fig. 1 Continued

Table 1. MRM conditions for 2'-deoxyguanosine and 8-hydroxy-2'-deoxyguanosine

\begin{tabular}{lcccc}
\hline \hline Compound & $\begin{array}{c}\text { Precursor ion } \\
(\mathrm{m} / \mathrm{z})\end{array}$ & $\begin{array}{c}\text { Product ion } \\
(\mathrm{m} / \mathrm{z})\end{array}$ & $\begin{array}{c}\text { Cone voltage } \\
(\mathrm{V})\end{array}$ & $\begin{array}{c}\text { Collision energy } \\
(\mathrm{eV})\end{array}$ \\
\hline $2^{\prime}$-Deoxyguanosine & 268.1 & 152.0 & 25 & 11 \\
2' $^{\prime}$-Deoxyguanosine- ${ }^{13} \mathrm{C}_{1},{ }^{15} \mathrm{~N}_{2}$ & 271.1 & 155.0 & 25 & 11 \\
8-Hydroxy-2' ${ }^{\prime}$-deoxyguanosine & 283.9 & 167.9 & 17 & 13 \\
8-Hydroxy-2' -deoxyguanosine- ${ }^{13} \mathrm{C}_{1}{ }^{15}{ }^{15} \mathrm{~N}_{2}$ & 286.9 & 170.9 & 17 & 13 \\
\hline
\end{tabular}

samples were incubated for $30 \mathrm{~min}$ at $40^{\circ} \mathrm{C}$. Then, the absorbance was measured at $540 \mathrm{~nm}$ with a BIO-RAD iMark $^{\mathrm{TM}}$ microplate reader. The effect of antioxidants on DPPH absorbance was estimated. DPPH scavenging activity was determined according to the following equation: \% scavenging activity $=[$ Abs. (control) - Abs. (sample) $] /[$ Abs. (control) - Abs. (ascorbic acid) $] \times 100$. DPPH plus ascorbic acid $(10 \mathrm{mmol} / \mathrm{L})$ was used as a positive control. The values of the effective concentration (concentration able to inhibit $50 \%$ of the oxidation $\left(\mathrm{EC}_{50}\right)$ ) were calculated from the inhibition percentage.

\section{Electron spin resonance measurement of hydroxyl rad- ical}

The ESR method was used for the determination of hydroxyl radicals $\left({ }^{\circ} \mathrm{OH}\right)^{3), 4)}$. Instead of directly trapping $\cdot \mathrm{OH}$, this method utilizes POBN to trap methyl radical $\left({ }^{\circ} \mathrm{CH}_{3}\right)$ that is formed by the interaction of DMSO with ' $\mathrm{OH}$, and measures the trapped ${ }^{\circ} \mathrm{CH}_{3}$. Moreover, this method can detect ${ }^{\circ} \mathrm{OH}$, which is not affected by copper ion. The analysis of ${ }^{\circ} \mathrm{CH}_{3}$ was carried out with an ESR spectrometer (JES-RE1X, JEOL Co., Tokyo, Japan). The
Table 2. Antioxidant activities of phenolic compounds as assessed by DPPH assay

\begin{tabular}{ccccc}
\hline \hline $\begin{array}{c}\text { Antioxidant } \\
\text { compound }\end{array}$ & $\begin{array}{c}\mathrm{EC}_{50} \\
(\mu \mathrm{mol} / \mathrm{L})\end{array}$ & & $\begin{array}{c}\text { Antioxidant } \\
\text { compound }\end{array}$ & $\begin{array}{c}\mathrm{EC}_{50} \\
(\mu \mathrm{mol} / \mathrm{L})\end{array}$ \\
\cline { 1 - 2 } \cline { 5 - 6 } Asc & 109 & & Ory & 196 \\
$\mathrm{CaA}$ & 106 & & PA & 2,295 \\
Ca & 96 & & Que & 49 \\
Cat & 64 & & Rut & 57 \\
ChA & 111 & & Semin & N.A. \\
Eug & 82 & & Semol & 135 \\
FA & 133 & & Toc & 129 \\
GA & 37 & & BHA & 89 \\
Gly & N.A. & & BHT & 128 \\
\hline
\end{tabular}

Final DPPH concentration was $50 \mu \mathrm{mol} / \mathrm{L}$. N.A.: no activity

ESR spectrum was measured at a microwave frequency of $9.43 \mathrm{GHz}$, a magnetic field of $336.0 \pm 5 \mathrm{mT}$, a microwave power of $9.0 \mathrm{~mW}$, a modulation of $100 \mathrm{kHz}$, a time constant of $0.03 \mathrm{~s}$, and a sweep time of $30 \mathrm{~s}$, using the ESR spectrometer. The spectra of the samples were scanned to record the signal intensities (peak-to-peak heights). 

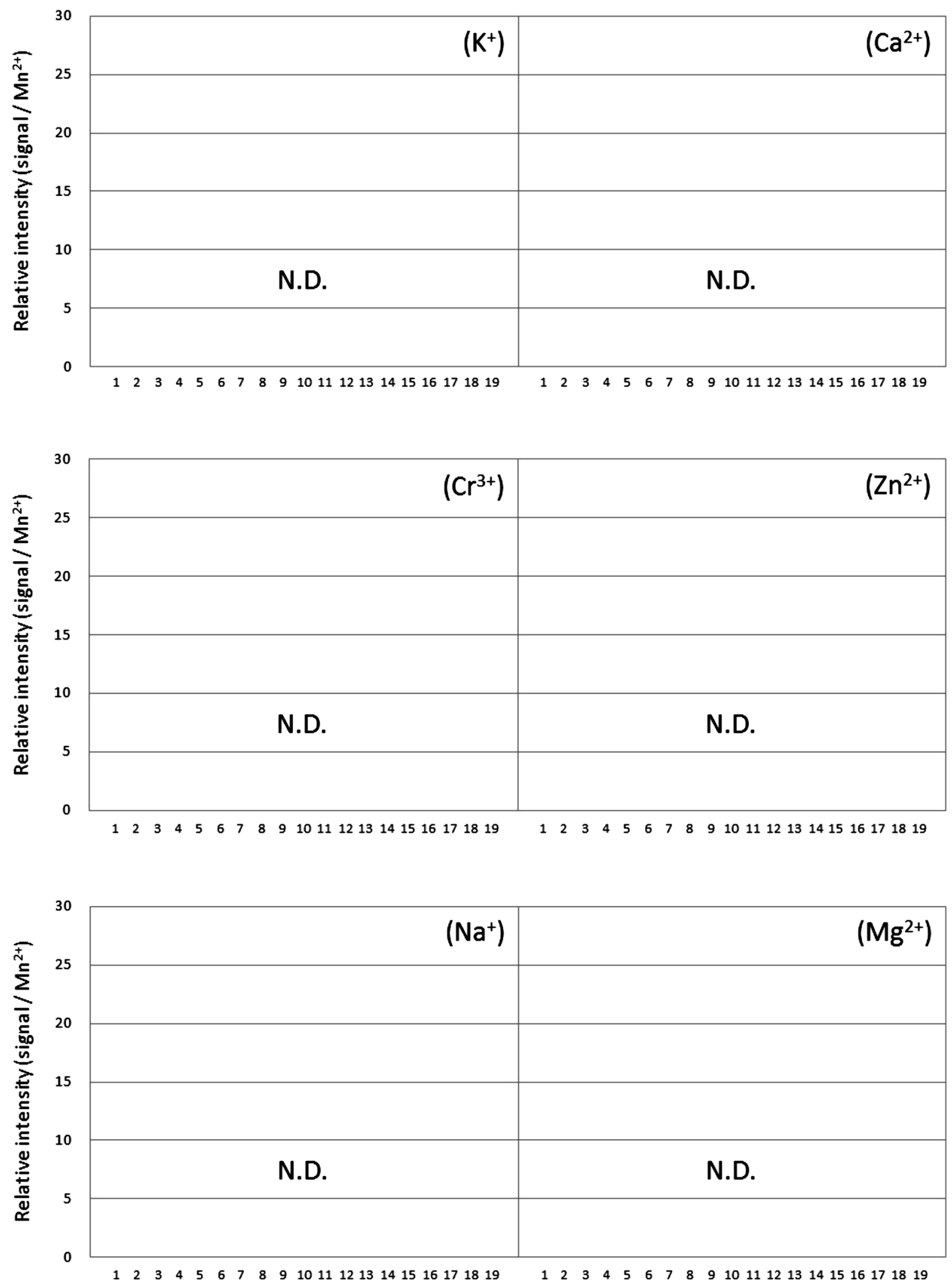

Fig. 2. Effect of various metal ions on pro-oxidant activities

Data are means \pm S.D. $(n=3)$

N.D.: not detected.

The sample solution $(0.3 \mathrm{~mL})$ containing phosphate-buffered saline (pH 7.4), POBN (10 mmol/L), DMSO (10\%), antioxidant $(1 \mathrm{mmol} / \mathrm{L})$, and metal ion $(1 \mathrm{mmol} / \mathrm{L})$ was incubated at $40^{\circ} \mathrm{C}$ for $30 \mathrm{~min}$, and then the ESR spectrum was measured under the conditions as described in Materials and Methods.

1. Control (methanol); 2. Ascorbic acid; 3. Caffeic acid; 4. Carnosic acid; 5. Catechin; 6. Chlorogenic acid; 7. Eugenol;

8. Ferulic acid; 9. Gallic acid; 10. Glycyrrhizin; 11. $\gamma$-Oryzanol; 12. Phytic acid; 13. Quercetin; 14. Rutin; 15. Sesamin;

16. Sesamol; 17. $\gamma$-Tocopherol; 18. 4-Hydroxy-3-tert-butylanisole; 19. Butylhydroxytoluene 

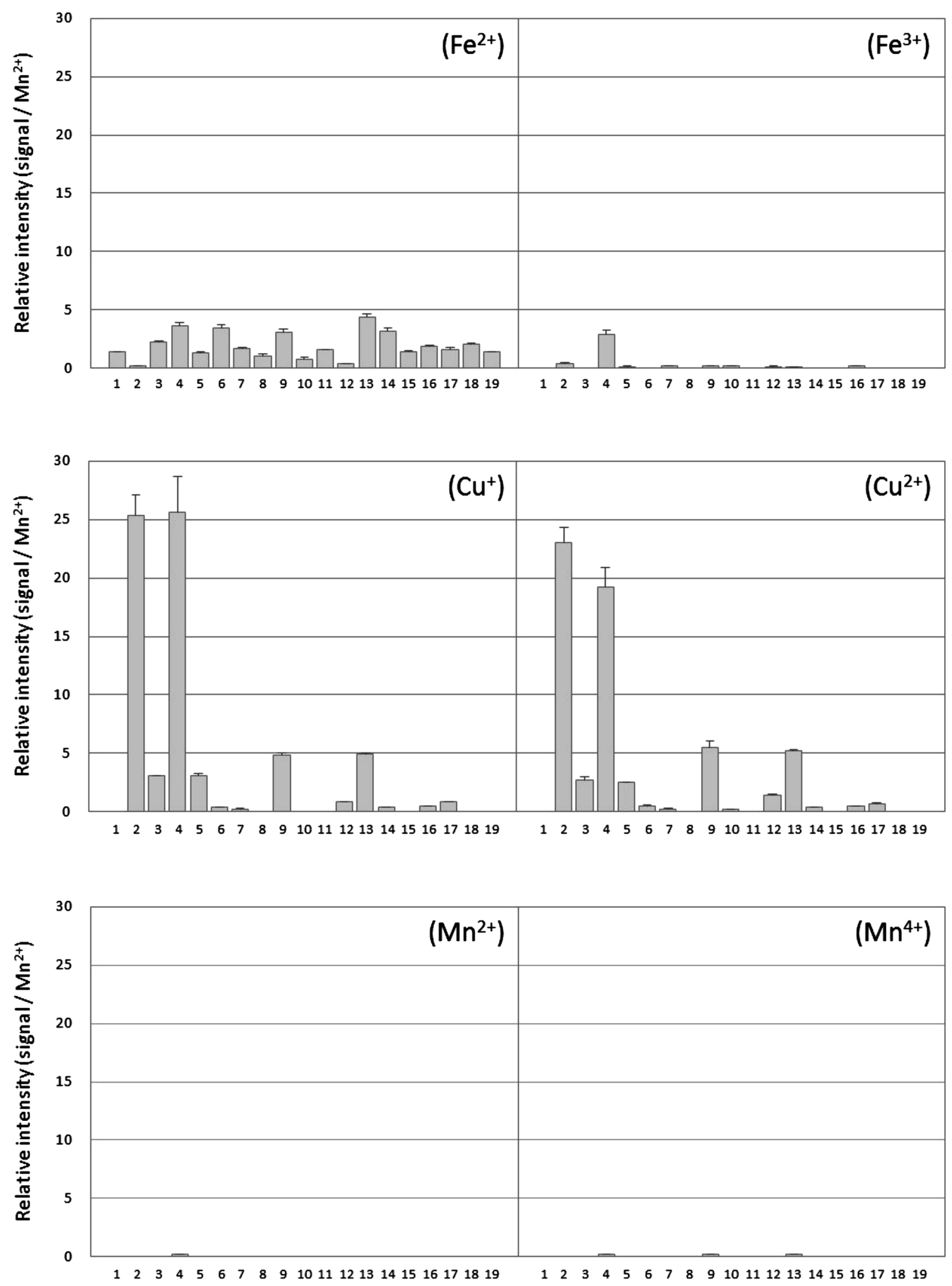

Fig. 2. Continued

A typical reaction mixture for incubation at $40^{\circ} \mathrm{C}$ for

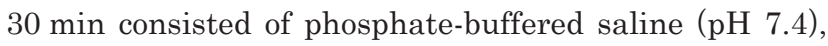
POBN (10 mmol/L), DMSO (10\%), antioxidant (1 mmol/L), metal ion $(1 \mathrm{mmol} / \mathrm{L})$, and hydrogen peroxide $(10 \mathrm{mmol} / \mathrm{L})$ in a final volume of $0.3 \mathrm{~mL}$.
4. DNA digestion and determination of $d G$ and 8-OHdG

In order to prevent the formation of oxidative by-products during DNA isolation, DNA was digested by using a slightly modification of our previous method ${ }^{3), 4)}$. Calf thymus DNA $(2 \mathrm{mg} / \mathrm{mL}, 0.4 \mathrm{~mL})$ was incubated at $40^{\circ} \mathrm{C}$ for $30 \mathrm{~min}$ after addition of $0.05 \mathrm{~mL}$ of antioxidant 

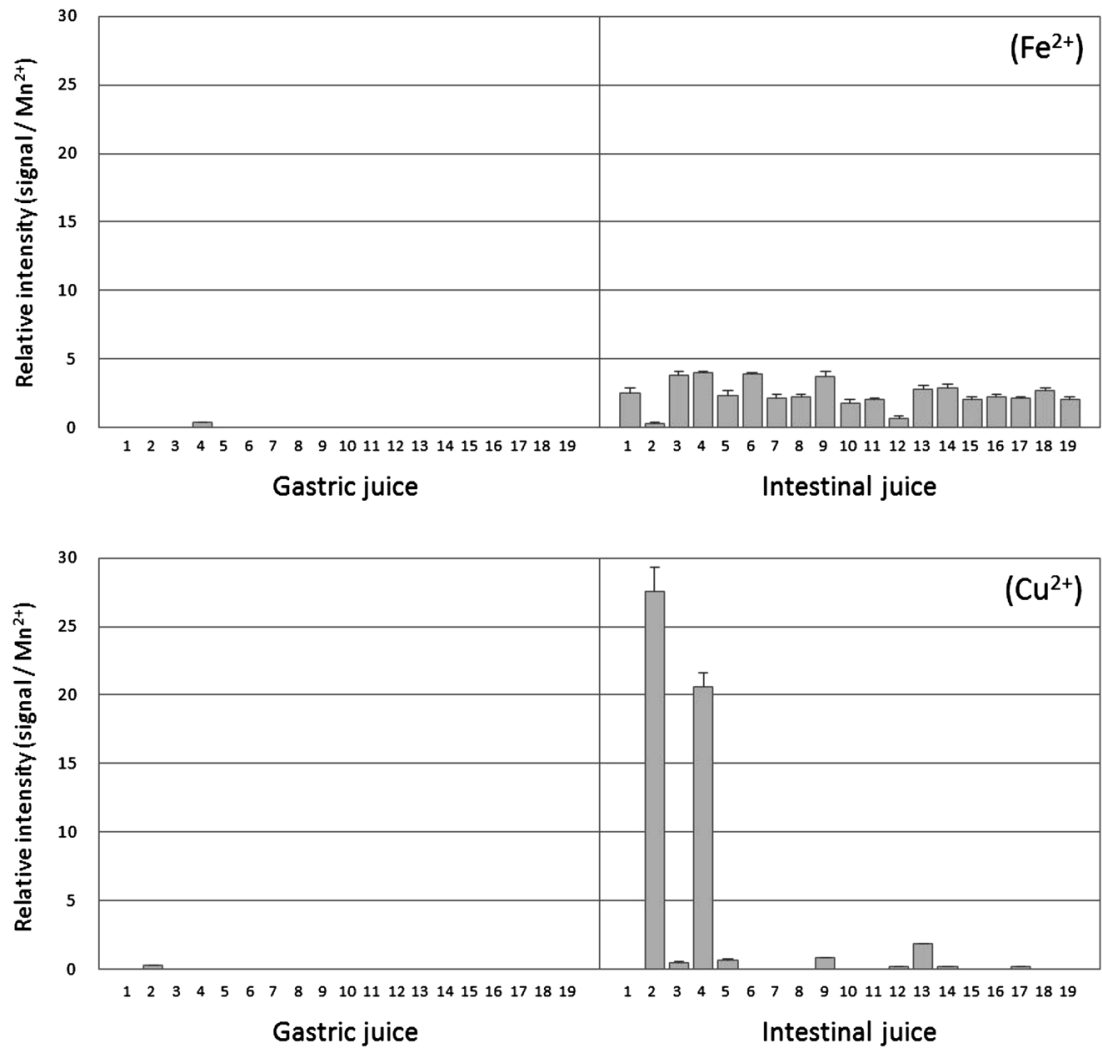

Fig. 3. Comparison of pro-oxidant activities in artificial gastric and intestinal juice

Data are means \pm S.D. $(n=3)$.

The sample solution $(0.3 \mathrm{~mL})$ containing artificial gastric or intestinal juice, POBN (10 mmol/L), DMSO (10\%), antioxidant $(1 \mathrm{mmol} / \mathrm{L})$, and metal ion $(1 \mathrm{mmol} / \mathrm{L})$ was incubated at $40^{\circ} \mathrm{C}$ for $30 \mathrm{~min}$, and then the ESR spectrum was measured under the conditions as described in Materials and Methods.

1. Control (methanol); 2. Ascorbic acid; 3. Caffeic acid; 4. Carnosic acid; 5. Catechin; 6. Chlorogenic acid; 7. Eugenol;

8. Ferulic acid; 9. Gallic acid; 10. Glycyrrhizin; 11. $\gamma$-Oryzanol; 12. Phytic acid; 13. Quercetin; 14. Rutin; 15. Sesamin;

16. Sesamol; 17. $\gamma$-Tocopherol; 18. 4-Hydroxy-3-tert-butylanisole; 19. Butylhydroxytoluene

( $1 \mathrm{mmol} / \mathrm{L}), 0.05 \mathrm{~mL}$ of $\mathrm{Cu}^{2+}(1 \mathrm{mmol} / \mathrm{L}), 0.05 \mathrm{~mL}$ of hydrogen peroxide $(10 \mathrm{mmol} / \mathrm{L})$, and $0.45 \mathrm{~mL}$ of phosphatebuffered saline ( $\mathrm{pH}$ 7.4). The treated calf thymus DNA was immediately centrifuged at $10,000 \times g$ for $5 \mathrm{~min}$ at $10^{\circ} \mathrm{C}$ after addition of $0.3 \mathrm{~mL}$ of $\mathrm{NaI}(7.6 \mathrm{~mol} / \mathrm{L})$ and $0.5 \mathrm{~mL}$ of 2 -propanol. The pellet was washed with $40 \%$ 2-propanol and 70\% ethanol, and then dissolved in $0.20 \mathrm{~mL}$ of sodium acetate buffer $(20 \mathrm{mmol} / \mathrm{L}, \mathrm{pH} 4.8)$ before adding $10 \mu \mathrm{L}$ of internal standard $(2 \mathrm{mmol} / \mathrm{L} \mathrm{dG}$ ${ }^{13} \mathrm{C}_{1},{ }^{15} \mathrm{~N}_{2}$ and $20 \mu \mathrm{mol} / \mathrm{L} 8-\mathrm{OHdG}-{ }^{13} \mathrm{C}_{1},{ }^{15} \mathrm{~N}_{2}$ ). DNA was enzymatically hydrolyzed by adding $5.0 \mu \mathrm{L}$ of nuclease $\mathrm{P} 1$ (500 units $/ \mathrm{mL}$ ). The mixture was incubated at $60^{\circ} \mathrm{C}$ for $15 \mathrm{~min}$. After the addition of $20 \mu \mathrm{L}$ of $1.0 \mathrm{~mol} / \mathrm{L}$ Tris $-\mathrm{HCl}$ buffer ( $\mathrm{pH} 8.0$ ), $5.0 \mu \mathrm{L}$ of alkaline phosphatase $(1,000$ units $/ \mathrm{mL}$ ) was added. The mixture was incubated at $40^{\circ} \mathrm{C}$ for $60 \mathrm{~min}$ and then passed through a 3,000 NMWL filter (Millipore, Tokyo, Japan). The digested solution was injected into the column-switching LC-MS/MS instrument for 8-OHdG and dG analysis.

LC-MS/MS analyses were performed using an Alliance HPLC system (Waters, Japan). On-line solid-phase extraction was accomplished on a Shodex ODP-50 4B column ( $50 \mathrm{~mm} \times 4.6 \mathrm{~mm}, 5 \mu \mathrm{m}$; Showa Denko, Japan) and analyte separation was achieved on a Shiseido Capcell
Pak C18 MGII column $(250 \mathrm{~mm} \times 2.0 \mathrm{~mm}, 5 \mu \mathrm{m}$; Shiseido, Japan). Column temperature was maintained at $40^{\circ} \mathrm{C}$ and the flow rate was set to $0.2 \mathrm{~mL} / \mathrm{min}$. The sample extract was injected onto the precolumn, which was flushed with $20 \mathrm{mmol} / \mathrm{L}$ acetate buffer $(\mathrm{pH} 4.7)$ at a flow rate of $0.3 \mathrm{~mL} / \mathrm{min}$. Mobile phases for separation were (A) water, (B) methanol, and (C) $100 \mathrm{mmol} / \mathrm{L}$ acetic acid. A gradient program was used as follows: 0-9 min, 5\% B and 5\% C; 9-10 min, 5-90\% B and 5\% C; 10-14.5 min, 90\% $\mathrm{B}$ and $5 \% \mathrm{C} ; 14.5-15 \mathrm{~min}, 90-5 \% \mathrm{~B}$ and $5 \% \mathrm{C}$; $15-$ $20 \mathrm{~min}, 5 \% \mathrm{~B}$ and $5 \% \mathrm{C}$. Autosampler temperature was set to $4{ }^{\circ} \mathrm{C}$ and $30 \mu \mathrm{L}$ was injected.

MS/MS detection was performed with a Micromass Quattro micro API triple quadrupole mass spectrometer (Waters) equipped with an electrospray ionization (ESI) source operating in the positive mode. The optimization results for the two most abundant ion transitions of analytes in the multiple reaction monitoring (MRM) mode are given in Table 1. The following optimum conditions were set: source temperature $120^{\circ} \mathrm{C}$ and desolvation temperature $500^{\circ} \mathrm{C}$. Cone and desolvation gas flow rates were set at 50 and $450 \mathrm{~L} / \mathrm{h}$, respectively. 

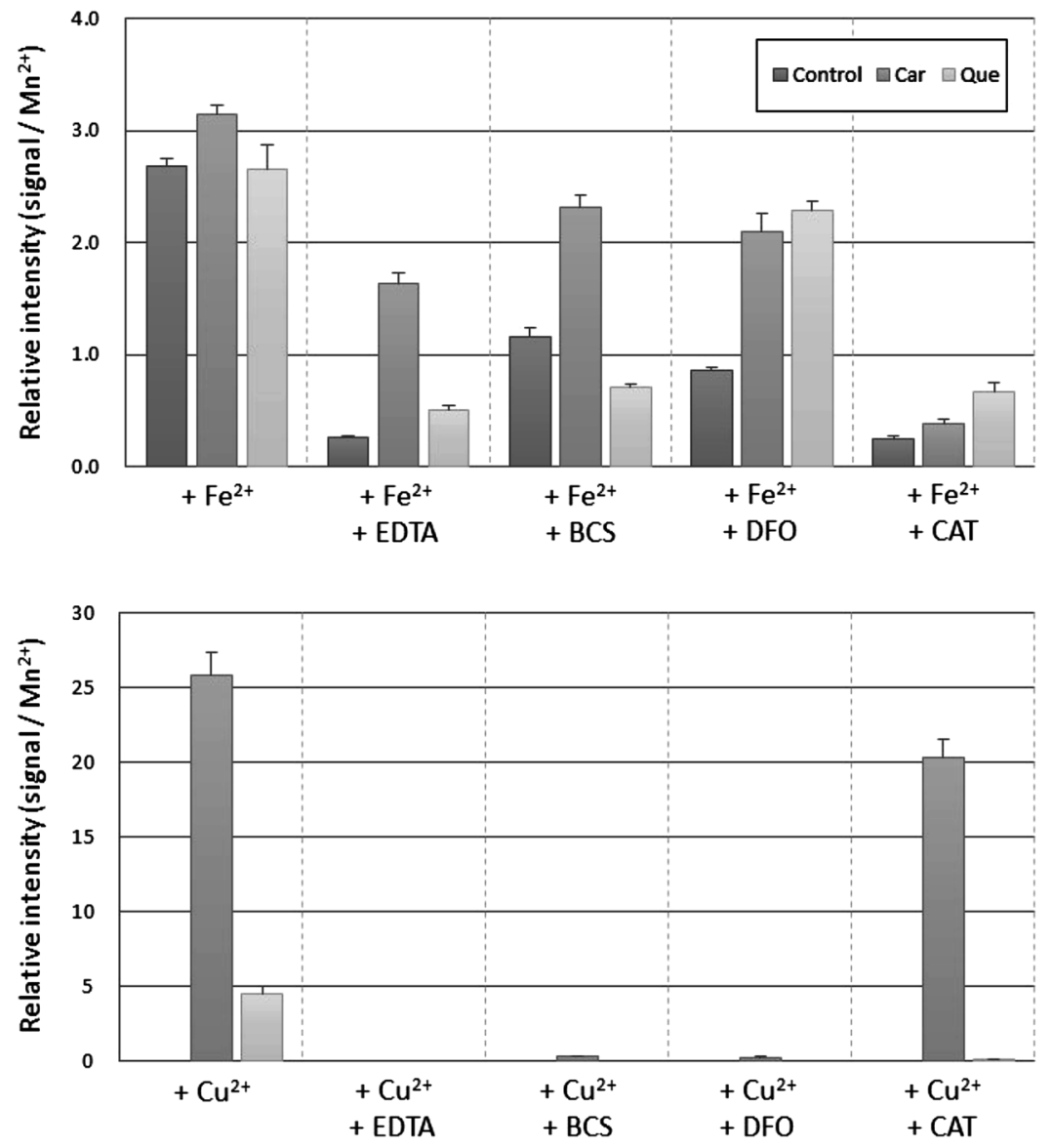

Fig. 4. Effect of chelators and enzymes on ROS generation

Data are means \pm S.D. $(n=3)$.

The sample solution $(0.3 \mathrm{~mL})$ containing phosphate-buffered saline $(\mathrm{pH} 7.4)$, POBN (10 mmol/L), DMSO (10\%), chelator $(10 \mathrm{mmol} / \mathrm{L})$, antioxidant $(1 \mathrm{mmol} / \mathrm{L})$, and metal ion $(1 \mathrm{mmol} / \mathrm{L})$ was incubated at $40^{\circ} \mathrm{C}$ for $30 \mathrm{~min}$, and then the ESR spectrum was measured under the conditions as described in Materials and Methods.

Control, methanol; Car, carnosic acid; Que, quercetin; EDTA, ethylenediamine- $N, N, N^{\prime}, N^{\prime}$-tetraacetic acid; BCS, bathocuproinedisulfonic acid; DFO, deferoxamine mesylate; CAT, catalase

\section{Agarose gel electrophoresis of DNA}

Electrophoresis was performed on $2 \%$ agarose gel in the presence of Tris-acetate buffer $(40 \mathrm{mmol} / \mathrm{L}$ Tris base, $20 \mathrm{mmol} / \mathrm{L}$ acetic acid, and $1 \mathrm{mmol} / \mathrm{L}$ EDTA; pH 8.0) and $0.5 \mu \mathrm{g} / \mathrm{mL}$ ethidium bromide. Treated DNA samples in sample buffer containing 5\% glycerol and 0.001\% bromophenol blue were applied to the well. DNA fragments were separated by electrophoresis at $100 \mathrm{~V}$ for $1 \mathrm{~h}$ and detected with a UV transilluminator.

\section{Results and Discussion}

1. Assessment of antioxidant activities of antioxidants used as food additives

Antioxidant activities were measured by the DPPH method, which is a well established method for evaluating antioxidant activity. Freshly prepared DPPH solution has a deep purple color with an absorption maximum at $517 \mathrm{~nm}$. This color generally disappears in the presence of an antioxidant. The scavenging effect of antioxidants on DPPH free radicals is summarized in Table 2. All the antioxidants showed strong antioxidant activities with the exception of Gly, PA, and Semin. Active compounds having more than one hydroxyl group on the aromatic ring, such as Cat, GA, Que, and Rut, tended to have high antioxidant activity.

Antioxidant activity blocks ROS-mediated damage (through radical scavenging) and/or suppresses the generation of ROS (by binding metal ion). Further, DPPH radical-scavenging activity was correlated with hydrogen peroxide-scavenging activity ${ }^{5}$. Dihydroxy substitution of phenolic compounds, i.e., an ortho-dihydroxy structure (catechol structure) of the B-ring, which possesses electron-donating properties and is a radical target, is important for antioxidant activity ${ }^{6}$.

\section{Effect of interaction between antioxidants and metal} ions on generation of reactive oxygen species

Minerals and trace elements are necessary for many physiological and biological functions. Iron, the most abundant transition metal in biological tissues, is an essential component of many important metalloproteins. Copper is a component of several metalloenzymes. Zinc 


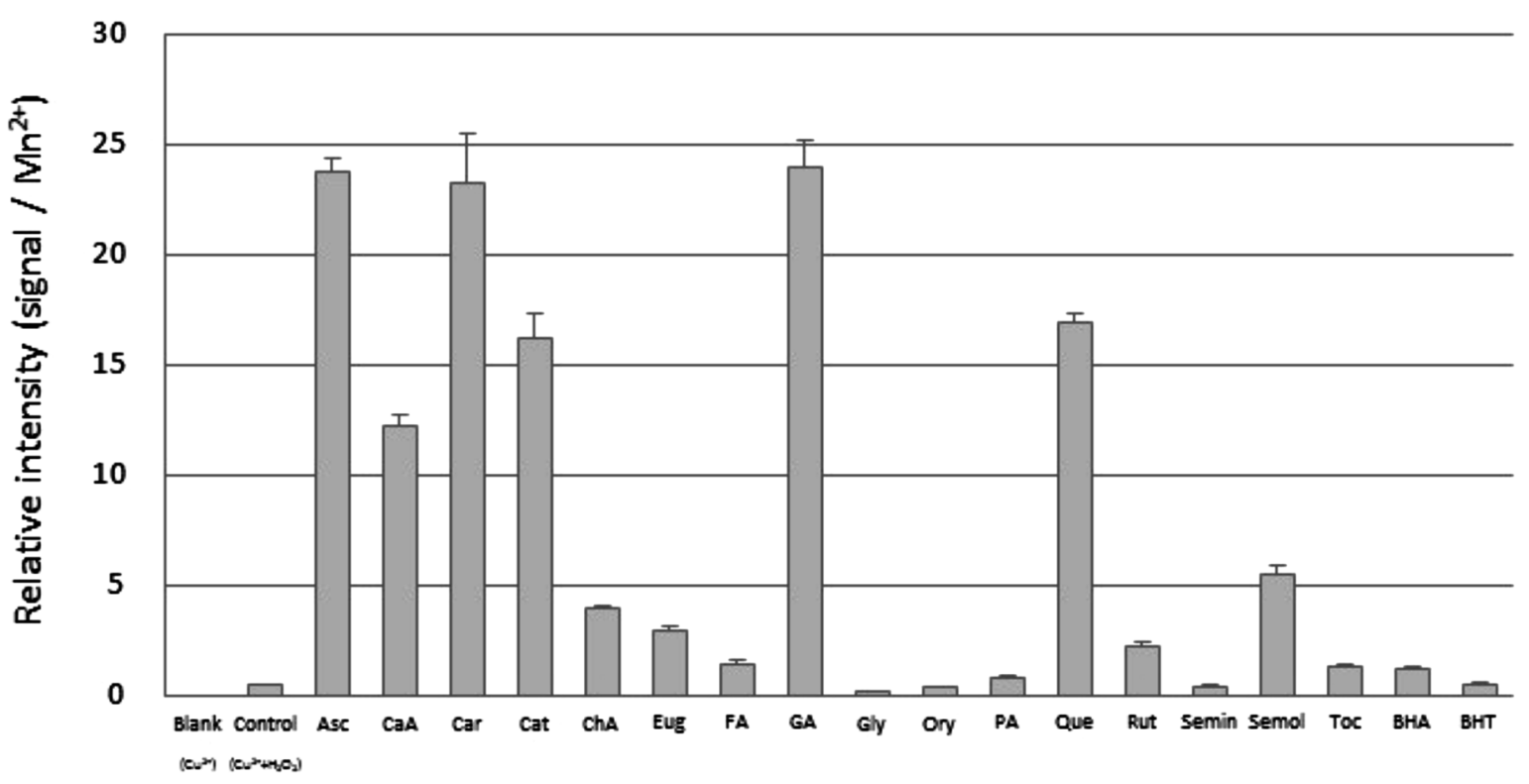

Fig. 5. Pro-oxidant activities of combinations of antioxidants, copper ion, and hydrogen peroxide

Data are means \pm S.D. $(n=3)$.

The sample solution (0.3 mL) containing phosphate-buffered saline (pH 7.4), POBN (10 mmol/L), DMSO (10\%), antioxidant $(1 \mathrm{mmol} / \mathrm{L})$, copper ion $(1 \mathrm{mmol} / \mathrm{L})$, and hydrogen peroxide $(10 \mathrm{mmol} / \mathrm{L})$ was incubated at $40^{\circ} \mathrm{C}$ for $30 \mathrm{~min}$, and then the ESR spectrum was measured under the conditions as described in Materials and Methods.

is implicated in the function of more than 200 enzymes. These minerals and trace elements are found not only in dietary foods but also in food supplements.

There are several methods for free radical determination, including fluorescence ${ }^{7)}$ and liquid chromatography $^{8}$. However, we selected ESR because it is specific and reliable. We measured ROS generated by the interaction between antioxidants and metal ions by ESR and evaluated the pro-oxidant activities of chromium, manganese, iron, copper, zinc, sodium, magnesium, potassium, and calcium. Among them, only iron $\left(\mathrm{Fe}^{2+}\right.$ and $\left.\mathrm{Fe}^{3+}\right)$ and copper $\left(\mathrm{Cu}^{+}\right.$and $\left.\mathrm{Cu}^{2+}\right)$ generated ROS by interacting with antioxidants. Copper $\left(\mathrm{Cu}^{+}\right.$and $\left.\mathrm{Cu}^{2+}\right)$ ions had the highest pro-oxidant activity (Fig. 2).

In our second series of experiments, the antioxidants were reacted with $\mathrm{Fe}^{2+}$ or $\mathrm{Cu}^{2+}$ in artificial gastric or intestinal juice. Low levels of ROS were generated by almost all antioxidants in the presence of $\mathrm{Fe}^{2+}$ in artificial intestinal juice. In the presence of $\mathrm{Cu}^{2+}$, substantial amounts of ROS were generated from Asc and Car, but not from other antioxidants, in artificial intestinal juice (Fig. 3). In gastric juice, no ROS generation was observed. ROS such as superoxide anion and hydroxyl radical are generated by degradation of hydrogen peroxide under alkaline conditions ${ }^{9)}$.

The effects of chelators and enzymes on ROS generation were next examined. EDTA, bathocuproinedisulfonic acid (BCS; a specific $\mathrm{Cu}^{+}$chelator), deferoxamine mesylate (DFO; a specific $\mathrm{Fe}^{3+}$ chelator) ${ }^{10)}$, and catalase (CAT; $\mathrm{H}_{2} \mathrm{O}_{2}$ scavenger) decreased ROS generation induced by antioxidants and metal ions (Fig. 4). DFO has a high affinity for $\mathrm{Fe}^{3+}$ but a very low affinity for $\mathrm{Fe}^{2+11)}$. BCS can chelate $\mathrm{Cu}^{+}$after reduction of $\mathrm{Cu}^{2+}$ to $\mathrm{Cu}^{+}$via electron transfer from antioxidants. Therefore, it seems reasonable to conclude that the pro-oxidant activity of antioxidants depends on the generation of hydrogen peroxide, by certain metal ions.

In general, phenolic compounds induce ROS in the presence of $\mathrm{Cu}^{2+}$. The finding that phenolic compounds showed higher reactivity for copper ions than other metal ions can be explained in terms of the redox potentials. For instance, the standard reduction potential of the $\mathrm{Cu}^{2+}$ / $\mathrm{Cu}^{+}$couple $(+0.15 \mathrm{~V})$ is much lower than those of the $\mathrm{Fe}^{3+} / \mathrm{Fe}^{2+}$ couple $(+0.77 \mathrm{~V})$ and the $\mathrm{Mn}^{3+} / \mathrm{Mn}^{2+}$ couple $(+1.56 \mathrm{~V})^{12), 13)}$. On the other hand, the redox potentials of phenolic compounds Que and Cat are $+0.40 \mathrm{~V}$ and + $0.44 \mathrm{~V}$, respectively ${ }^{14)}$. Antioxidants can reduce $\mathrm{Cu}^{2+}$ to $\mathrm{Cu}^{+}$. However, iron and manganese cannot induce the redox cycle because they require a high redox potential to reduce the metal. Consequently, redox cycling in the presence of an antioxidant, leading to various ROS, occurs only with copper ion.

\section{Measurement of hydroxyl radical and oxidative dam- age in calf thymus DNA}

It is well known that copper or iron ions can induce ' $\mathrm{OH}$ generation through the Fenton reaction in the presence of hydrogen peroxide. Our results indicated that antioxidants have both antioxidant and pro-oxidant activities. Thus, we examined the interactions among antioxidant, hydrogen peroxide, and copper ion by ESR and found that Asc, CaA, Car, Cat, GA, and Que all promoted ROS generation via the Fenton reaction (Fig. 5).

Increasing oxidative stress mediated by ROS causes DNA oxidation, which is involved in the pathogenesis of various diseases, such as cancer. Thus, we measured 8-OHdG, a DNA oxidative stress marker, by means of column-switching LC-MS/MS. We found that almost all 


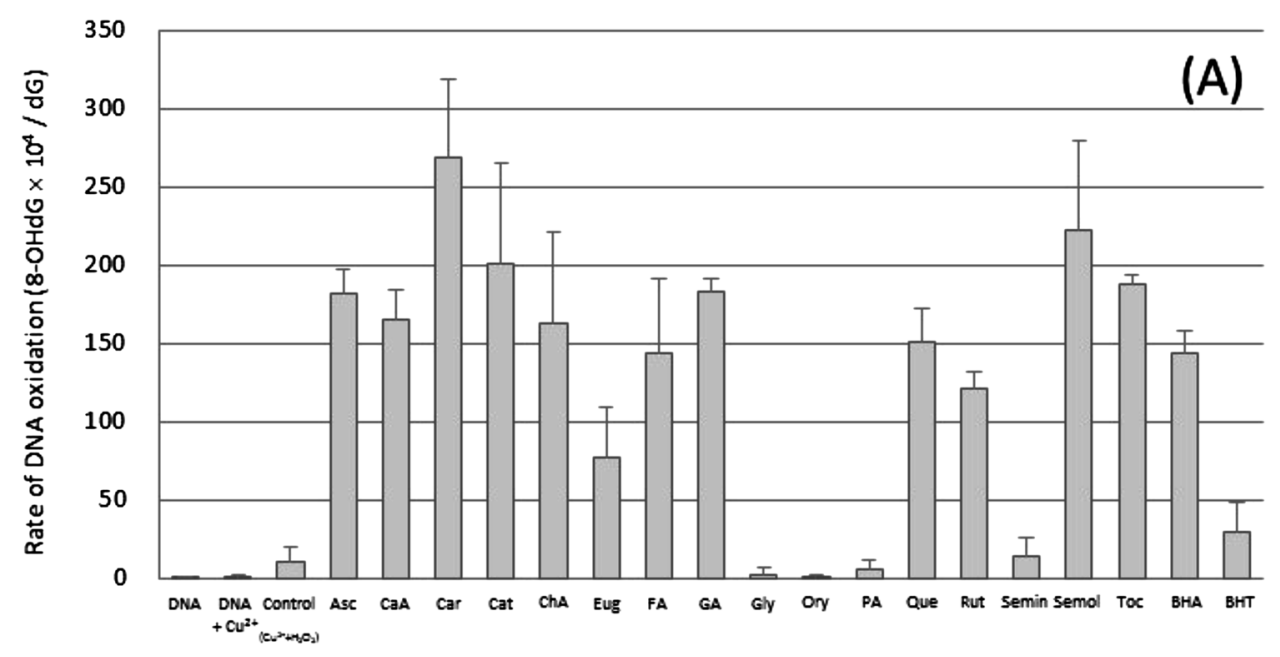

(B)
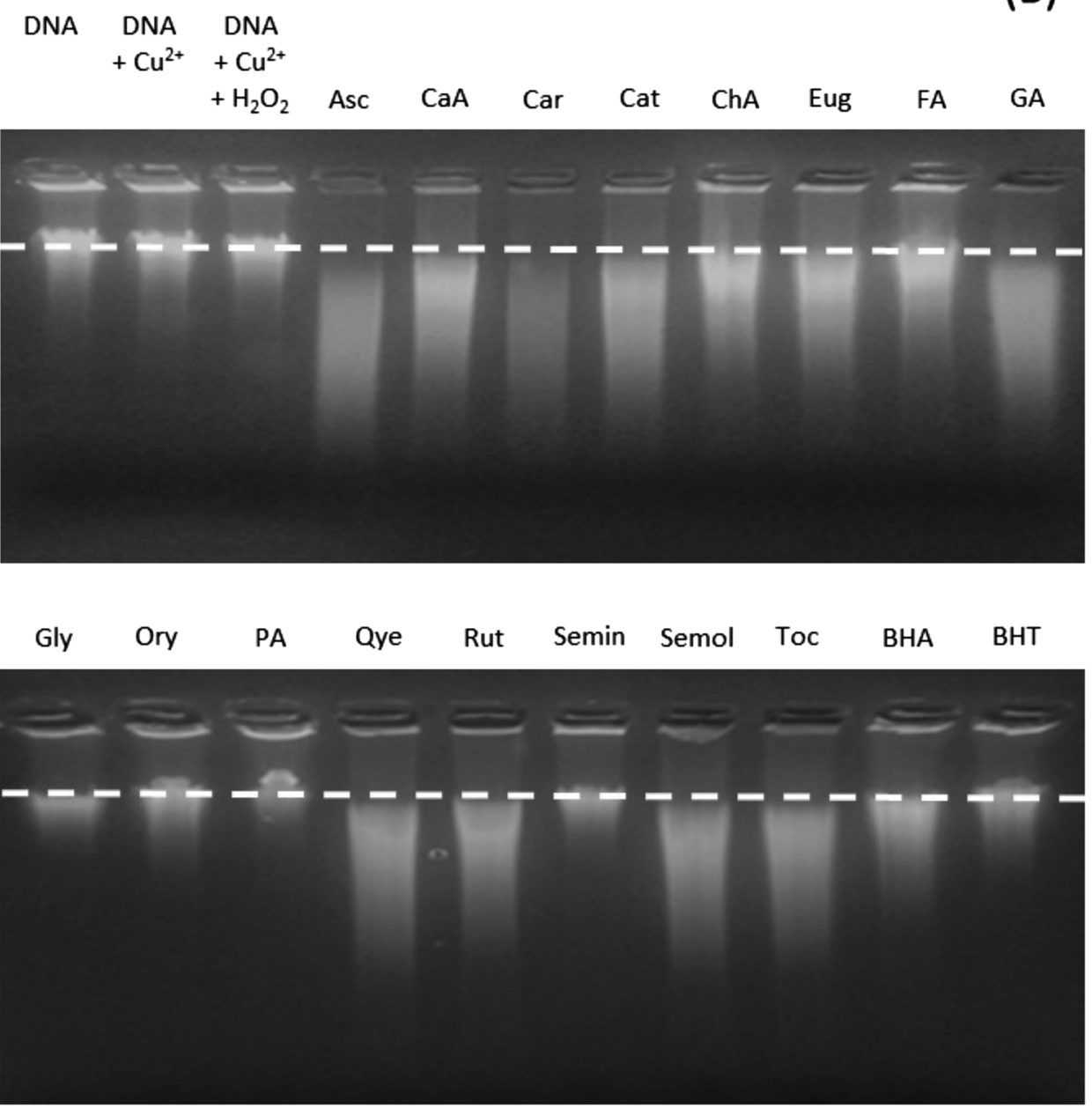

Fig. 6. Analysis of oxidation and degradation of DNA from calf thymus by (A) column-switching LC-MS/MS and (B) agarose gel electrophoresis with UV detection

of the antioxidants examined induced DNA oxidation and degradation, in agreement with the ESR results (Fig. 6). There were some of inconsistencies with the ESR data, but antioxidants can behave both as antioxidants and pro-oxidants, depending on many factors, such as concentration, reaction rate or experimental conditions. It is noteworthy that Asc and Car generated high levels of
ROS in the presence of copper ion, and caused complete DNA degradation. Colorectal cancer is associated with both genetic predisposition and inflammation ${ }^{15)}$, and inflammation is associated with the release of large amounts of ROS and RNS leading to oxidation of nucleic acids.

Our results indicate that combinations of high concen- 
trations of antioxidants and certain metal ions can generate large amounts of ROS in artificial intestinal juice. Further studies will be needed to evaluate the physiological significance of these findings.

\section{Conclusion}

Our results show that phenolic antioxidants generate ROS in the presence of iron and copper ions. In particular, compounds with ortho-dihydroxy groups may chelate $\mathrm{Cu}^{2+}$ to generate the highest pro-oxidant activity. The initial electron-transfer oxidation by $\mathrm{Cu}^{2+}$ generates the corresponding semiquinone radical, which would undergo a second electron-transfer reaction with $\mathrm{O}_{2}$ to form ortho-quinone and superoxide anion $\left(\mathrm{O}_{2}^{-}\right)$. Then $\mathrm{O}_{2}^{-}$reacts with $\mathrm{Cu}^{+}$to produce hydrogen peroxide, which is readily converted into ${ }^{\circ} \mathrm{OH}$ via a Fenton-like reaction ${ }^{16)}$. Thus, certain antioxidants can generate large amounts of ROS in the presence of copper ion, and induce DNA degradation in vitro. The physiological significance of this reaction remains to be investigated.

\section{Acknowledgment}

This work was supported by The Japan Food Chemical Research Foundation.

\section{References}

1) Inoue, K., Shibutani, M., Masutomi, N., Toyoda, K. Takagi, H., Uneyama, C., Nishikawa, A., Hirose, M. A 13-week subchronic toxicity study of madder color in F344 rats. Food Chem. Toxicol., 46, 241-252 (2008).

2) Inoue, K., Yoshida, M., Takahashi, M., Fujimoto, H., Ohnishi, K., Nakashima, K., Shibutani, M., Hirose, M., Nishikawa, A. Possible contribution of rubiadin, a metabolite of madder color, to renal carcinogenesis in rats. Food Chem. Toxicol., 47, 752-259 (2009).

3) Iwasaki, Y., Hirasawa, T., Maruyama, Y., Ishii, Y., Ito, R., Saito, K., Umemura, T., Nishikawa, A., Nakazawa, H. Effect of interaction between phenolic compounds and copper ion on antioxidant and pro-oxidant activities. Toxicol. In Vitro, 25, 1320-1327 (2011).

4) Iwasaki, Y., Nomoto, M., Oda, M., Mochizuki, K., Nakano, Y., Ishii, Y., Ito, R., Saito, K., Umemura, T., Nishikawa, A., Nakazawa, H. Characterization of nitrated phenolic compounds for their anti-oxidant, pro-oxidant, and nitration activities. Arch. Biochem. Biophys., 513, 10-18 (2011)

5) Sroka, Z., Cisowski, W. Hydrogen peroxide scavenging, antioxidant and anti-radical activity of some phenolic acids. Food Chem. Toxicol., 41, 753-758 (2003).

6) Promden, W., Monthakantirat, O., Umehara, K., Noguchi, H., De-Eknamkul, W. Structure and antioxidant activity relationships of isoflavonoids from Dalbergia parviflora. Molecules, 19, 2226-2237 (2014).

7) Aranda, A., Sequedo, L., Tolosa, L., Quintas, G., Burello, E., Castell, J. V., Gombau, L. Dichloro-dihydro-fluorescein diacetate (DCFH-DA) assay: a quantitative method for oxidative stress assessment of nanoparticle-treated cells. Toxicol. in Vitro, 27, 954-963 (2013).

8) Kilinc, E. Determination of the hydroxyl radical by its adduct formation with phenol and liquid chromatography/ electrochemical detection. Talanta, 65, 876-881 (2005).

9) Yamaguchi, F., Yoshimura, Y., Nakazawa, H., Ariga, T. Free radical scavenging activity of grape seed extract and antioxidants by electron spin resonance spectrometry in an $\mathrm{H}_{2} \mathrm{O}_{2} / \mathrm{NaOH} / \mathrm{DMSO}$ system. J. Agric. Food Chem., 47, 2544-2548 (1999)

10) Sooriyaarachchi, M., Gailer, J. Removal of $\mathrm{Fe}^{3+}$ and $\mathrm{Zn}^{2+}$ from plasma metalloproteins by iron chelating therapeutics depicted with SEC-ICP-AES. Dalton Trans., 39 7466-7473 (2010).

11) Klebanoff, S. J., Waltersdorph, A. M., Michel, B. R., Rosen, H. Oxygen-based free radical generation by ferrous ions and deferoxamine. J. Biol. Chem., 264, 19765-19771 (1989).

12) Li, J., Fisher, C. L., Chen, J. L., Bashford, D., Noodleman, L. Calculation of redox potentials and $\mathrm{p} K_{\mathrm{a}}$ values of hydrated transition metal cations by a combined density functional and continuum dielectric theory. Inorg. Chem. 35, 4694-4702 (1996)

13) Mira, L., Fernandez, M. T., Santos, M., Rocha, R., Florêncio, M. H., Jennings, K. R. Interactions of flavonoids with iron and copper ions: a mechanism for their antioxidant activity. Free Radic. Res., 36, 1199-1208 (2002).

14) Zettersten, C., Co, M., Wende, S., Turner, C., Nyholm, L., Sjöberg, P. J. Identification and characterization of polyphenolic antioxidants using on-line liquid chromatography, electrochemistry, and electrospray ionization tandem mass spectrometry. Anal. Chem., 81, 8968-8977 (2009).

15) Tudek, B., Speina, E. Oxidatively damaged DNA and its repair in colon carcinogenesis. Mutat. Res., 736, 8292 (2012).

16) Fan, G. J., Jin, X. L., Qian, Y. P., Wang, Q., Yang, R. T., Dai, F., Tang, J. J., Shang, Y. J., Cheng, L. X., Yang, J., Zhou, B. Hydroxycinnamic acids as DNA-cleaving agents in the presence of $\mathrm{Cu}$ (II) ions: mechanism, structureactivity relationship, and biological implications. Chemistry, 15, 12889-12899 (2009). 